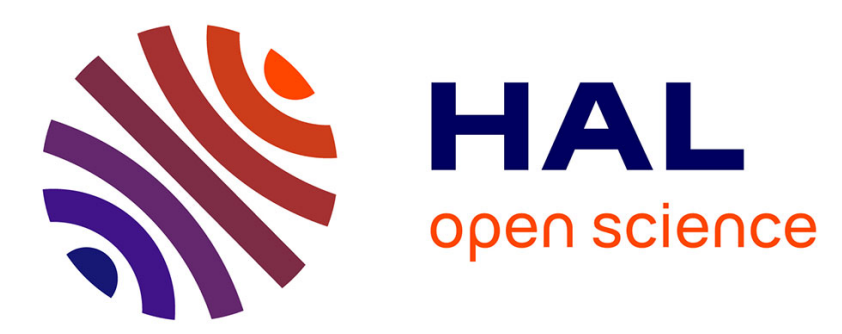

\title{
Synthesis of Chiral Non Racemic Indolizidin-3-ones as Peptidomimetic Scaffold
}

\author{
Delphine Halie, Joelle Pérard-Viret, Jacques Royer
}

\section{To cite this version:}

Delphine Halie, Joelle Pérard-Viret, Jacques Royer. Synthesis of Chiral Non Racemic Indolizidin3-ones as Peptidomimetic Scaffold. Heterocycles, 2006, 68 (12), pp.2471. 10.3987/COM-06-10891 . hal-03384848

\author{
HAL Id: hal-03384848 \\ https://hal.science/hal-03384848
}

Submitted on 19 Oct 2021

HAL is a multi-disciplinary open access archive for the deposit and dissemination of scientific research documents, whether they are published or not. The documents may come from teaching and research institutions in France or abroad, or from public or private research centers.
L'archive ouverte pluridisciplinaire HAL, est destinée au dépôt et à la diffusion de documents scientifiques de niveau recherche, publiés ou non, émanant des établissements d'enseignement et de recherche français ou étrangers, des laboratoires publics ou privés. 


\title{
SYNTHESIS OF CHIRAL NON RACEMIC INDOLIZIDIN-3-ONES AS PEPTIDOMIMETIC SCAFFOLD
}

\section{Delphine Halie, Joëlle Pérard-Viret and Jacques Royer*}

UMR 8638 (CNRS-University Paris5), Faculty of Pharmacy, 4 avenue de l’Observatoire, 75270 Paris cedex 06, France

\begin{abstract}
A new asymmetric strategy has been devised to attain indolizidin-3-ones wich can be used as peptidomimetic scaffolds. The sequence is a two-step synthesis.
\end{abstract}

Local constraint of peptide geometry has been widely considered as a useful strategy for attaining peptide secondary structure or modifying the specificity for a receptor and could be achieved through the properties of cyclic dipeptide mimetics. ${ }^{1}$ Further possibilities to functionalize these mimics is also of great interest as this would allow the introduction of lipophilic moieties or known drugs (for vectorisation) or others. ${ }^{2}$ In this context, we developped the preparation of the indolizidone structure (1) (Figure 1), which could be further derivatized to (2) countaining all the required structural features: a constrained bicyclic dipeptide bearing an extra functional group for the attachment of other entities. The indolizidinone skeleton has been largely used as a scaffold for the design and elaboration of constrained peptidomimetics ${ }^{3}$ but mainly as indolizidin-5-one and rather scarcely as indolizidine-3-one 2 (or C-terminal pipecolic acid). ${ }^{4}$ We now present herein a new approach toward a total asymmetric synthesis of this later type of compound.<smiles>[R]OC(=O)C1CC([X])CC2CCC(=O)N21</smiles><smiles>[X]C1CC2CC(N)C(=O)N2C(C(=O)O)C1</smiles>

1 $\mathrm{X}=\mathrm{OH}, \mathrm{OR}^{\prime}$

\section{Figure 1}


The synthesis of racemic 1 was already reported in the literature ${ }^{5}$ but is difficult to adapt in an asymmetric manner. We preferred a different strategy also based on the acyliminium ion cyclization ${ }^{6}$ and using the chemistry developed in our laboratory for some years. The key step is the cyclization to an acyliminium derived from chiral $\alpha, \beta$-unsaturated $\gamma$-lactam. ${ }^{7}$

Some years ago, we reported the condensation of primary amines with dimethoxydihydrofuran to give $\alpha, \beta$-unsaturated $\gamma$-lactam. The later was the precursor of an acyliminium species (through acidic treatment) and then, if the starting amine bears a nucleophilic function, cyclization can occur quite readily according to the following scheme (Scheme 1)

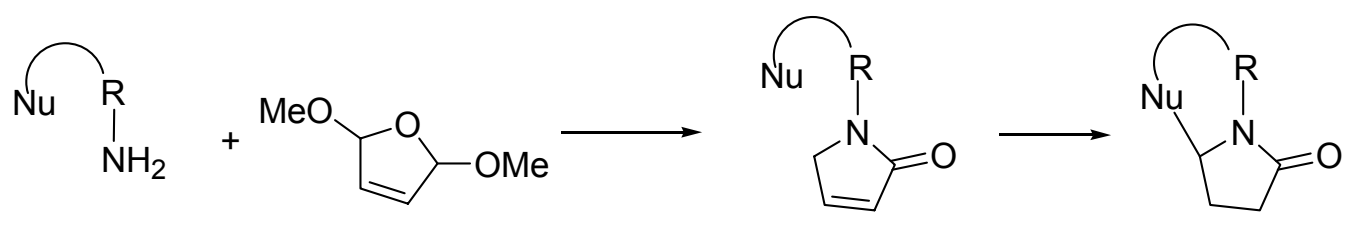

\section{Scheme 1}

By the use of this strategy, we also already reported that electron-enriched aromatics led in a one-pot sequence to bicyclic lactams. ${ }^{8}$ We now want to extend this reaction to olefin cyclization: in this case a nucleophilic terminator is necessary to stabilize the so-formed carbocation.

We started with the condensation of rac-methyl allylglycinate and dimethoxydihydrofuran which gave the $\gamma$-lactam (3) as a mixture of $\alpha, \beta / \beta, \gamma$-unsaturated regioisomers $(\mathbf{3 a}+\mathbf{3 b})$ in a $55 \%$ overall yield after purification.
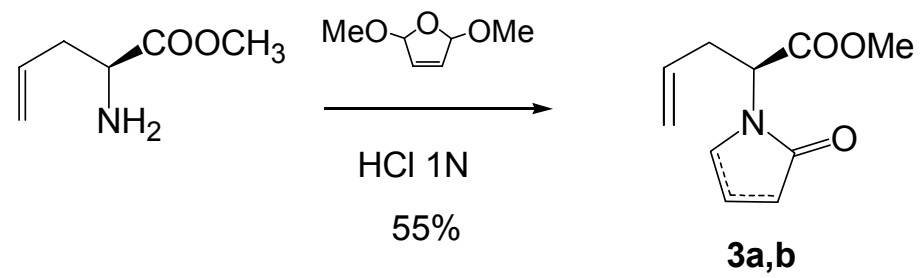

\section{Scheme 2}

The treatment of this regioisomeric mixture with various nucleophiles $\mathrm{XH}$ and under acidic conditions allowed the attempt cyclization to occur. Nevertheless, depending upon the nucleophile and the experimental conditions, cyclization proceeded with various yields and was, in some cases, accompanied by transesterification products. The table shows the different attempts. Water was first tried as a nucleophile in limited amount and in various solvents to avoid ester hydrolysis (Entries 1-3). While no cyclization was observed in dioxan, 1a was isolated in DME (in low yield) and in $\mathrm{CF}_{3} \mathrm{CH}_{2} \mathrm{OH}$ (Entry 3 ). Two experiments were conducted in benzyl alcohol (Entries 4,5) with the hope to directly introduce a benzyl ether group. Indeed, while there was no cyclization at rt, the two cyclization products (1a and 1b) obtained in dichloroethane at $90^{\circ} \mathrm{C}$ bear a free $\mathrm{OH}$ group showing a poor nucleophilicity of this alcohol. When the cyclizations were conducted with $\mathrm{H}_{2} \mathrm{SO}_{4}$ in methanol, free alcohol (1a) was still present but accompanied (1/1 mixture) with the methoxy derivative (1c) (Entry 7). The use of acetonitrile (Entry 9) was 
of great interest since a Ritter reaction took place to give an interesting amide (compound 1f) but unfortunately, we were not able to rise the yield to satisfactory values.

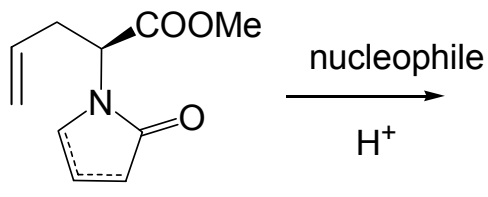

3

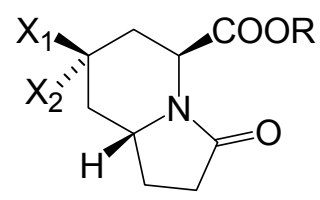

1

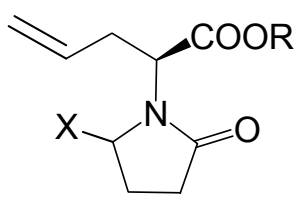

4

a $\mathrm{X}_{1}=\mathrm{OH}, \mathrm{X}_{2}=\mathrm{H}, \mathrm{R}=\mathrm{Me} \quad$ a $\mathrm{X}=\mathrm{OH}, \mathrm{R}=\mathrm{H}$

b $\mathrm{X}_{1}=\mathrm{OH}, \mathrm{X}_{2}=\mathrm{H}, \mathrm{R}=\mathrm{Bn} \quad$ b $\mathrm{X}=\mathrm{OBn}, \mathrm{R}=\mathrm{Me}$

c $X_{1}=H, X_{2}=O M e, R=M e \quad$ c $X=O M e, R=M e$

d $\mathrm{X}_{1}=\mathrm{OCHO}, \mathrm{X}_{2}=\mathrm{H}, \mathrm{R}=\mathrm{Me}$

e $\mathrm{X}_{1}=\mathrm{H}, \mathrm{X}_{2}=\mathrm{OCHO}, \mathrm{R}=\mathrm{Me}$

f $\mathrm{X}_{1}=\mathrm{NHCOCH}_{3}, \quad \mathrm{X}_{2}=\mathrm{H}$,

$\mathrm{R}=\mathrm{Me}$

Scheme 3

Entry Nucleophile

conditions

Product (yield)

\begin{tabular}{|c|c|c|c|}
\hline & $\mathrm{H}_{2} \mathrm{O}$ & & \\
\hline 1 & $\mathrm{H}_{2} \mathrm{SO}_{4}$, dioxane, $60{ }^{\circ} \mathrm{C}, 16 \mathrm{~h}$ & - & $4 \mathbf{a}(20 \%)$ \\
\hline 2 & Amberlist, DME, rt, 4days & 1a $(25 \%)^{*}$ & - \\
\hline \multirow[t]{2}{*}{3} & $\mathrm{H}_{2} \mathrm{SO}_{4}, \mathrm{CF}_{3} \mathrm{CH}_{2} \mathrm{OH}, \mathrm{rt}, 16 \mathrm{~h}$ & $1 \mathbf{a}(45 \%) *$ & \\
\hline & $\mathrm{PhCH}_{2} \mathrm{OH}$ & & \\
\hline 4 & $\mathrm{CSA}, \mathrm{rt}, 3 \mathrm{~h}\left(\mathrm{CH}_{2} \mathrm{Cl}_{2}\right)$ & - & $4 b(40 \%)$ \\
\hline \multirow[t]{2}{*}{5} & $\mathrm{CSA}, 90^{\circ} 3 \mathrm{~h}\left(\mathrm{ClCH}_{2} \mathrm{CH}_{2} \mathrm{Cl}\right)$ & $\mathbf{1 a}(16 \%)+\mathbf{1 b}(45 \%)$ & - \\
\hline & $\mathrm{MeOH}$ & & \\
\hline 6 & $\mathrm{H}_{2} \mathrm{SO}_{4}$, reflux, $3 \mathrm{~h}$ & - & $4 c(93 \%)$ \\
\hline \multirow[t]{2}{*}{7} & $\mathrm{H}_{2} \mathrm{SO}_{4}$, reflux, 20h & $\mathbf{1 a}(27 \%)+\mathbf{1 c}(31 \%)$ & - \\
\hline & $\mathrm{HCOOH}$ & & \\
\hline 8 & reflux, $4 \mathrm{~h}$ & $\mathbf{1 d + 1 e}(91 \%)(1: 1.5)$ & - \\
\hline \multirow[t]{2}{*}{9} & $\mathrm{CH}_{3} \mathrm{CN}$ & & \\
\hline & $\mathrm{H}_{2} \mathrm{SO}_{4}, 55^{\circ} \mathrm{C}, 2 \mathrm{~h}$ & $\mathbf{1 f}(26 \%)+\mathbf{1 a}(7 \%)$ & - \\
\hline
\end{tabular}

*low amounts $(<10 \%)$ of other cyclized products showing the introduction of a molecule of solvent were detected but not fully characterized.

Table

Eventually when the reaction was conducted in formic acid the formation of the two epimeric formates (1d) and (1e) (1:1.4) was observed in 91\% yield. 
Careful examination of the relative configuration of compounds 1a-e revealed that the cyclization process was totally diastereoselective (the configuration at C-8a was as depicted on Scheme 3. It was also noteworthy that alcohols (1a and $\mathbf{1 b}$ ) possessed an unique cis configuration relative to the ester function in contrast to methoxy derivative 1c which exhibited a trans configuration while the formates $(\mathbf{1 d} / \mathbf{1 e})$ were formed as $1 / 1.4$ mixture.

These observations are in agreement with the following mechanism (Scheme 4) of cyclization first proposed by Speckamp. It was suggested that the ester present in the structure can intramolecularly trap the carbenium ion $\mathbf{B}$ giving $\mathbf{C}$. To this last structure the nucleophilic species $\mathrm{XH}=\mathrm{HOH}, \mathrm{PhCH}_{2} \mathrm{OH}, \mathrm{MeOH}$ ...can add along path a) to furnish trans-1c, 1e or along path b) to give only cis alcohol (1a,b). The formation of formate (cis-1d) can be explained by a rapid esterification of 1a in $\mathrm{HCOOH}$ medium

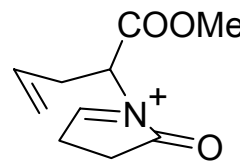

A

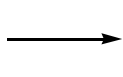

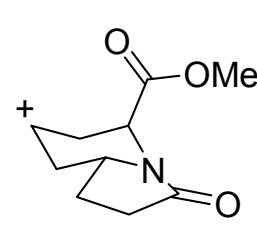

B

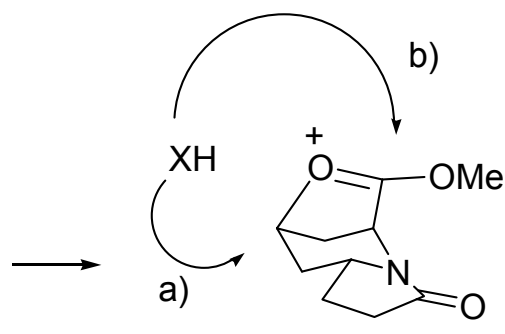

C
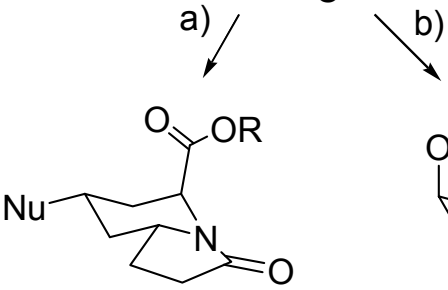

1c, e

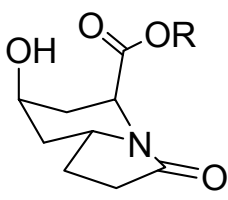

$1 \mathrm{a}, \mathrm{b}$

Scheme 4

At that stage, very simple processes were established to attain the target compounds, with fixed configuration. Reflux in formic acid (Entry 8) gave access to a diastereomeric mixture but in very high yield. Conditions were found to stereoselectively access the cis alcohol in acceptable combined yields (Entries 3 and 5).

An important aspect should now be examined and is concerned with the possible application of this scheme in the chiral non-racemic series. The question is to be addressed since it was early reported that the iminium ion cyclization may be accompanied by a partial, or total racemization through a possible aza-Cope rearrangement. ${ }^{9}$

Indeed, a brief review of the literature revealed that the presence of the ester group was not a favorable structural feature for such a rearrangement. ${ }^{10,11}$

The reaction sequence was then conducted with chiral non-racemic methyl allylglycinate and the cyclization carefully checked. 
Enantiomerically pure $(S)$-allylglycine $\left([\alpha]_{\mathrm{D}}{ }^{20}-36.5\left(\mathrm{c} 4.0, \mathrm{H}_{2} \mathrm{O}\right)\right.$; it. $^{12}$ : $\left.[\alpha]_{\mathrm{D}}{ }^{20}-37.1\left(\mathrm{c} 4.0, \mathrm{H}_{2} \mathrm{O}\right)\right)$ was prepared according to the literature ${ }^{12}$ and the corresponding methyl ester $\left([\alpha]_{\mathrm{D}}^{33} 8.4\right.$ (c $\left.1.0, \mathrm{MeOH}\right)$, lit. $^{13}$ $\left.[\alpha]_{\mathrm{D}}{ }^{20} 8.3(\mathrm{c} 1.0, \mathrm{MeOH})\right)$ subjected to condensation to give $\mathbf{3 a} \mathbf{a}, \mathbf{b}$. The cyclization of $\mathbf{3 a}, \mathbf{b}$ in formic acid gave the expected bicyclic lactam $(\mathbf{1 d}+1 \mathbf{1 e})$ in $47 \%$ overall yield from $(S)$-allylglycine. These compounds were the only products of the cyclization process. Diastereomers (1d and 1e) were separated by column chromatography on silica gel and the integrity of the chiral center of the starting material was checked on each compound. Cis-isomer (5S, 7S, $8 \mathrm{a} R)-(\mathbf{1 d})^{14}$ as well as trans-compound $(5 \mathrm{~S}, 7 \mathrm{R}, 8 \mathrm{a} R)-(\mathbf{1 e})^{15}$ were both found as single isomer by HPLC analysis on chiral column ${ }^{16}$ (the racemic compound (1d) nicely exhibited a two peaks pattern of equal intensities with a $\Delta \mathrm{Rt}=8 \mathrm{~min}$. and the racemic 1e two peaks of equal intensities and a $\Delta \mathrm{Rf}=1 \mathrm{~min}$.).

The presented sequence is thus applicable to the preparation of the enantiomerically pure target compound. It appears as a rapid and efficient synthesis of such intermediates. (MS Word Style "05 Het-Text")

\section{REFERENCES (AND NOTES)}

1. a) A. Giannis and T. Kolter, Angew. Chem., Int. Ed. Engl., 1993, 32, 1244. b) C. Toniolo in "Methods of organic chemistry" (Houben-Weyl) G. Thieme Verlag Ed. Stuttgart 2003, vol E22c, page 693. c) M. Kahn and M. Eguchi, ibid. page 695.

2. a) K. Temming, R. M. Schiffelers, G. Molema, and R. J. Kok, Drug Resistance Updates, 2005, 8, 381. b) X. Chen, C. Plasencia, Y. Hou and N. Neamati, J. Med. Chem., 2005, 48, 1098. c) Z. Cheng, Y. Wu, Z. Xiong, S. S. Gambhir and X. Chen Bioconjugate Chem., 2005, 16, 1433.

3. a) J. Cluzeau and W. D Lubell, Biopolymers, 2005, 80, 98. b) W. Maison and A. H. G. P. Prenzel, Synthesis, 2005, 1031.

4. a) J. Cluzeau and W. D. Lubell, J. Org. Chem., 2000, 65, 2163. b) W. Wang, C. Xiong, and V. J. Hruby, Tetrahedron Lett., 2001, 42, 3159. c) C. Lamazzi, S. Carbonnel, P. Calineau, and Y. Troin Heterocycles, 2003, 60, 1447. d) M. Shimizu, H. Nemoto, H. Kadura, and H. Takahata, Heterocycles, 2003, 59, 245.

5. P. M. Esch, F. de Boer, H. Hiemstra, I. M. Boska, and W. N. Speckamp, Tetrahedron, 1991, 47, 4063.

6. J. Royer, M. Bonin, and L. Micouin, Chem. Rev. 2004, 104, 2311.

7. a) I. Baussanne, A. Chiaroni, C. Riche, J. Royer, and H.-P. Husson, Tetrahedron Lett., 1994, 35, 3931. b) I. Baussanne and J. Royer Tetrahedron Lett., 1996, 37, 1213. c) I. Baussanne and J. Royer Tetrahedron Lett., 1998, 39, 845. d) I. Baussanne, C. Travers, and J. Royer, Tetrahedron: Asymmetry, 1998, 9, 797.

8. H. Fontaine, I. Baussanne, and J. Royer, Synth.Commun., 1997, 27, 2817.

9. a) H. E. Shoemaker, J. Dijkink, and W. N. Speckamp Tetrahedron, 1978, 34, 163. b) S. J. Veenstra, K. 
Hauser, W. Schilling, C. Betschart, and S. Ofner, Bioorg. Med. Chem. Lett., 1996, 6, 3029. c) D. J. Hart and Y.-M. Yeun-Min Tsai, Tetrahedron Lett., 1981, 22, 1567.

10. F. P. J. T. Rutjes, J. J. N. Veerman, W. J. N. Meester, H. Hiemstra, and H. E. Schoemaker, Eur. J. Org. Chem. 1999, 5, 1127.

11. It could be also assumed that the integrity of the chiral center chiral was preserved through the 3,3-sigmatropic rearrangement since a new chiral center was formed during the rearrangement.

12. J. C. Russell, W. A. Sherwin, L. K. P. Lam, and J. C. Vederas, J. Am. Chem. Soc., 1996, 118, 7449.

13. R. Kaul, S. Surprenant, and W. D. Lubell, J. Org. Chem. 2005, 70, 3838.

14. (5S, 7S, 8aR)-1d : $[\alpha]_{\mathrm{D}}^{33}-19.6$ (c 1. 0, $\left.\mathrm{CHCl}_{3}\right)$, HRMS $\left(\mathrm{ES}^{+},[\mathrm{MNa}]^{+}\right)$calcd : 264,0848 ; found : 264,0857. ${ }^{1} \mathrm{H}$ NMR (400MHz, $\left.\mathrm{CDCl}_{3}\right) \delta(\mathrm{ppm}): 1.19$ (1H, ddd, J=12.0 Hz, H8), 1.34 (1H, m, H1), $1.64(1 \mathrm{H}, \mathrm{ddd}, \mathrm{J}=14.8,7.0,2.2 \mathrm{~Hz}, \mathrm{H} 6), 1.86(1 \mathrm{H}, \mathrm{d}, \mathrm{J}=12.0 \mathrm{~Hz}, \mathrm{H} 8), 2.1(3 \mathrm{H}, \mathrm{m}, \mathrm{H} 1$ and 2H2), 2.31 $(1 \mathrm{H}, \mathrm{d}, \mathrm{J}=14.8 \mathrm{~Hz}, \mathrm{H} 6), 3.42$ (3H, s, Me), 3.70 (1H, ddd, J=11.5, 8.0, 3.5 Hz, H8a), 4.47 (1H, d, J=6.9, H5), 5.00 (1H, m, H7), $\left.7.58(1 \mathrm{H}, \mathrm{s}, \mathrm{CHO}) ;{ }^{13} \mathrm{C} \mathrm{NMR} \mathrm{(100} \mathrm{MHz,} \mathrm{CDCl}_{3}\right) \delta(\mathrm{ppm}): 25.6,29.5,29.9$, $35.8,47.8,49.1,52.2,66.7,159.7,170.5,174.5$.

15. (5S, 7R, 8aR)-1e : $[\alpha]_{\mathrm{D}}{ }^{33}-29.7\left(\mathrm{c} 1.0, \mathrm{CHCl}_{3}\right),{ }^{1} \mathrm{H}$ NMR $\left(400 \mathrm{MHz}, \mathrm{CDCl}_{3}\right) \delta(\mathrm{ppm}): 1.23(1 \mathrm{H}, \mathrm{ddd}$, $\mathrm{J}=11.7 \mathrm{~Hz}, \mathrm{H} 8), 1.60(2 \mathrm{H}, \mathrm{m}, \mathrm{H} 6$ and H1), 2.20 (2H, m, H1 and H8), 2.40 (3H, m, H6 and 2H2), 3.69 (3H, s, Me), 3.82 (1H, ddd, J=11.7, 7.5, 3.4 Hz, H8a), 4.89 (2H, m, H5 and H7), 7.95 (1H, s, CHO); ${ }^{13} \mathrm{C}$ NMR $\left(100 \mathrm{MHz}, \mathrm{CDCl}_{3}\right) \delta(\mathrm{ppm}): 25.2,30.0,31.2,38.0,49.7,52.7,53.0,67.5,160.1,170.3$, 174.2.

16. Chiral pack AD column, $250 \mathrm{~mm}$, n-hexane $/ \mathrm{EtOH} 85 / 15, \Delta \mathrm{Rt}=2 \mathrm{~min}$. 